\title{
The influence of teaching media in learning English language
}

\section{Saodatkhan KHODJAEVA ${ }^{1}$}

Uzbek State University of World Languages

\begin{tabular}{l} 
ARTICLE INFO \\
\hline Article history: \\
Received February 2021 \\
Received in revised form \\
20 February 2021 \\
Accepted 15 March 2021 \\
Available online \\
15 April 2021 \\
\hline
\end{tabular}

\section{Keywords:}

influence,

teaching media,

English language teaching, media literacy.

\begin{abstract}
This article is devoted to the study of the issue of teaching media in learning language. The use of mass media to teach language in authentic context represents a double challenge for language teachers. Teaching media is one of important part in delivering the subject. Especially for the students as second language learners. Teacher needs to have media as strategy to attract the students to learn English in order to reach the goal of teaching learning.

2181-1415/@ 2021 in Science LLC.

This is an open access article under the Attribution 4.0 International (CC BY 4.0) license (https://creativecommons.org/licenses/by/4.0/deed.ru)
\end{abstract}

\section{Чет тилни ўқитишда Оммавий ахборот воситаларининг таъсири}

\footnotetext{
Калит сўзлар:

таъсир, медиа ўқитиш, инглиз тилини ўқитиш, медиа саводхонлик.
}

\begin{abstract}
АННОТАЦИЯ
Ушбу мақола инглиз тилини ўрганишда оммавий ахборот воситаларини ўқитиш масалаларини ўрганишга бағишланган. Инглиз тилини ўқитиш учун оммавий ахборот воситаларидан фойдаланиш филологларга учун икки томонлама муаммо туғдиради. Оммавий ахборот воситалари инглиз тилини иккинчи тил сифатида ўрганаётган талабалар учун ўқитишнинг мухим қисми хисобланади. Шу сабабли оммавий ахборот воситалари ўқитувчига талабаларни инглиз тилини ўрганишга жалб қилиш ва ўқув мақсадига эришиш стратегияси сифатида мухим ахамиятга эга.
\end{abstract}

\footnotetext{
${ }^{1}$ senior lecturer, Uzbek State University of World Languages, Tashkent, Uzbekistan.
} 


\section{Влияние средств массовой информации в преподавании английского языка}

\author{
Ключевые слова: \\ влияние, \\ обучающие медиа, \\ преподавание \\ английского языка, \\ медиа грамотность.
}

\section{АННОТАЦИЯ}

Данная статья посвящена исследованию проблемы преподавания средств массовой информации при изучении английского языка. Использование СМИ для обучения в аутентичном контексте представляет собой двойную задачу для филологов. Обучающие СМИ - одна из важных составляющих преподавания предмета, особенно для студентов, изучающих английский как второй язык. Преподавателю необходимы средства массовой информации в качестве стратегии для привлечения студентов к изучению английского языка и для достижения цели обучения.

The media, if used in the educational setting will complement the teaching-learning process. It will make the English language teaching better and more effective, and will also 'enhance the students' ability to understand and experiment with the language.

Generally, teaching media mean all tools, which may be used by teacher to deliver teaching material to students in teaching learning process to reach certain learning goals.

The term media was first used to describe newspapers more than two centuries ago. Today media has many different connotations. For instance, there are mass media, print media, visual media and teaching media. While media can take on many different forms, the purpose of all media is universally the same - media is a channel of communication.

Media literacy is typically defined as the ability to access, analyze, evaluate, and produce communication in a variety of forms (The Module "Oral and written speech" Media in English) incorporated into the practical course of ELT defines media very broadly, including books, newspapers, magazines, videos, movies, recorded music, and everything available via the Internet. Special emphasis, though, is to be put on multimedia.

According to the suggested approach, the module is designed to develop students' skills to interpret mass media messages as well as awareness of the reasons and methods of how these messages are often mispresented, misinterpreted, and, as a result, might become instruments for manipulating the audience.

In this paper we examined how with the Module designed within the present project, students may have a better understanding of the mass media information, if the syllabus, methods of teaching and support materials in the media-oriented ELT classroom could enhance their critical thinking and media literacy.

While the use of media in the language class is still something of a novelty, it's worth pointing out that the application of traditional communicative teaching techniques to the students' media literacy development can, with a bit of imagination, flexibility, and bias towards mass media evaluation, critical analysis and interpretation, pay handsome returns. The teaching strategy proposed and used within the project follows the classical model of previewing, while viewing and after-viewing activities.

Developing students' media literacy through integrating English and mass media resources (multimedia form) into the English classroom is a challenging, demanding task for the language teacher who must possess interdisciplinary knowledge and keep developing it alongside with the students. Both the teacher and the students have to fully 
understand that media literacy is essential for successful cross-cultural communication. In this article, we propose that integrating mass media into the ELT classroom by means of the Module Oral and written speech - "Media in English incorporated into the practical course of ELT is a noteworthy form of weaving students" media literacy development.

There are various media learning strategies that could be useful for enhancing the learning process. Practical examples portraying the applicability of media sources in learning are:

$\checkmark$ Film clips - which could serve as a means of depicting rare and uncommonly seen events $\checkmark$ Songs

$\checkmark$ Podcast of a lecture

$\checkmark$ Or newspaper article.

It is noteworthy that students can also be more creative with their own learning. As an example, student video projects can provide an excellent and highly rewarding learning experience.

Media can be used in direct instruction, active learning teaching strategies and student projects.

Existing media resources can be used within lectures to stimulate interest in and develop knowledge of the material being taught. This traditional approach is teachercentric, and information is pushed to the learner. Media allows the instructor to facilitate the transfer of expert knowledge to novice learners. Given the tremendous rate of technological change, instructors face an ongoing challenge in choosing the most effective media platform to reach their students. Instructors can also create their own media to effectively and efficiently convey knowledge. The quality of teaching media should meet the determined standard. For instance, if a picture is used as the teaching media, the picture should be very clear otherwise it cannot help A teaching media should suit the students intelligence level because it will successfully help them understand the material.

A teaching media for students with high intelligence must be different from what is used for low-achiever students. If the intelligent students are given a low level teaching media, they will not develop because they will find it too easy and if the low-achiever students are given a very difficult teaching media, they will get nothing at all, the students to understand the material.

Before deciding to use the teaching media in classroom, teacher should select the appropriate media used to assist him in teaching language to the students.

A teacher should consider the appropriateness media to the material, the affordability to be made or financed, the availability of hardware to facilitate the teaching media, the easiness of using the teaching media, the quality of the teaching media, the suitability to the students' needs and intelligence level.

There are many ways to identify and classify teaching media based on the physical characteristics, nature, complexity, or control of using. However, we can classify teaching media into three classification based on its physical characteristics. Teachers should use teaching media for language learning because it motivates students and offers a different mode of presentation. A teaching media should suit the students intelligence level because it will successfully help them understand the material. The selection of instructional media should be in line with the standards of competence and indicators set is basically an extension of communication skills that require a detailed process, systematic and specific.

Generally, designing a teaching media can be done by doing these following steps: 
1. Identifying what the students need. In designing a teaching media, it should be based on what the students need. So that is why the teacher should try to identify what the students need so that the teaching media will function well. A teaching media can also be designed based on the curriculum so that it help the student to master what they are tasked to.

2. Determining instructional objective. The teacher should determine the objective to achieve by using a teaching media. This is made based on what the students need. A standard should also be made as the instructional objective. Instructional objective can be in the form of behavior that the students are expected to have.

3. Determining the material. The teacher should then determine which parts of the material that will be included. This contains the materials that will be given to the students.

4. Start composing the teaching media. After the materials that will be included have been decided, a teaching media can then be composed based on those materials. The teacher can also write a script about which material to teach first and which material to teach later on and with what way.

The function of learning media for students:

- Improve learning and learner motivation,

- Provide and improve learner learning variations,

- Provide subject matter structure and facilitate learners to learn,

- Provide the core information, subjects systematically so as to facilitate learning in learning,

- Stimulate learners to be more focus,

- Create the conditions and situations of learning without pressure, and Learners can understand the subject matter presented systematically teaching through the medium of learning.

Language teaching media are very important to help students acquire new concepts of, the skills and language competences. There are many kinds of media which can be used by the teachers in the teaching learning process, but the teacher should be selective when he is choosing kinds of media.

\section{REFERENCE:}

1. Potter J.W. (2004). Theory of Media Literacy: A cognitive approach. London: Sage.

2. Romiszowski A.J. 2008. The Selection and use of Instructional Media. London.

3. Savu E. (2014). The "intercultural teacher" - a new response to the teaching career. Procedia - Social and behavioral Sciences, 128, 11 - 116.

4. Silverblatt A. (2001). Media literacy: Keys to interpreting media messages (2nd ed.). Westport. 